\title{
PERANAN KARBOHIDRAT DAN PROTEIN \\ PADA FASE PEMULIHAN PASCA-LATIHAN
}

\author{
Dian Rahadianti \\ Fakultas Kedokteran Universitas Islam Al-Azhar \\ Jl. Unizar No.20 Turida Mataram
}

\begin{abstract}
ABSTRAK
Fase berakhirnya latihan atau periode pemulihan pasca-latihan (post exercise recovery) merupakan salah satu bagian dari latihan yang dapat diatur dalam memperbaiki performa latihan endurance melalui strategi nutrisi pasca-latihan untuk pemulihan latihan yang optimal. Gambaran dan diskusi beberapa penelitian dengan fokus pada efek pemberian karbohidrat dan kombinasi karbohidratprotein setelah latihan pada fase pemulihan dihubungkan dengan tingkat glikogen otot dan onset kelelahan menunjukkan hasil yang bervariasi pada performa latihan. Meskipun demikian penelitian yang telah dilakukan sebelumnya menunjukkan bahwa asupan karbohidrat maupun kombinasi karbohidrat-protein merupakan suatu pedoman yang dapat dijadikan sebagai dasar dalam pengelolaan adaptasi selama latihan untuk meningkatkan kapasitas dan kepatuhan dalam berpartisipasi dalam latihan/olahraga.
\end{abstract}

Kata Kunci : Karbohidrat, Protein, Pemulihan Pasca Latihan, Endurance

\section{PENDAHULUAN}

Periode pemulihan pasca-latihan(post exercise recovery) merupakan fase berakhirnya latihan atau kontraksi otot disertai dengan perubahan metabolisme yang berlawanan dibandingkan pada saat/selama latihan. Pada periode pemulihan terjadi transisi dari fase latihan masuk ke fase istirahat dalam mencapai homeostasis. Proses ini terjadi dalam hitungan menit hingga beberapa jam diikuti atau bersamaan dengan pengisian kembali sumber energi dan fungsi rekonstruksi khususnya struktur seluler dan sistem enzim (Viru, 1999).

\footnotetext{
Nutrisi pemulihan pasca-latihan adalah bagian integral dari rejimen pelatihan pada atlet dan individu aktif yang fundamental dalam meningkatkan performa
}

latihan/olahraga. Penurunan glikogen otot selama awal latihan yang berkelanjutan merupakan faktor utama dalam timbulnya kelelahan dan dengan demikian pengisian simpanan glikogen sangat penting untuk pemulihan pasca-latihan. Ketersediaan glikogen otot pada akhir pemulihan menentukan kapasitas untuk latihan yang berulang sehingga penipisan glikogen otot terbukti menjadi penentu utama kelelahan. Konsumsi protein setelah latihan diketahui meningkatkan sintesis protein otot di luar periode pasca-latihan akut dan dengan demikian memodulasi adaptasi latihan yang diinduksi oleh olahraga. Namun, apakah konsumsi protein pasca latihan meningkatkan besarnya adaptasi latihan endurance masih belum jelas.

Metabolisme adalah istilah yang 
digunakan untuk menggambarkan banyak reaksi kimia yang terlibat dalam pemanfaatan nutrisi dalam tubuh. Metabolisme terdiri dari dua kategori yaitu yang dikenal sebagai anabolisme (membangun senyawa yang lebih kompleks dari senyawa yang sederhana hasil dari pencernaan) dan katabolisme (memecah senyawa kompleks ini untuk menghasilkan energi yang berperan pada fungsi tubuh normal).

Nutrien utama atau substrat yang digunakan saat istirahat dan selama berlatih yaitu simpanan karbohidrat (glikogen), glukosa darah, simpanan lipid. Energi dari substrat ini dimanfaatkan dengan masuk ke dalam jalur metabolisme dan digunakan untuk menghasilkan adenosin trifosfat (ATP). Pada saat istirahat, ATP disediakan melalui pemecahan lemak dan karbohidrat. Dengan bertambahnya intensitas latihan dari intensitas rendah ke tinggi, maka terjadi pergeseran penggunaan karbohidrat semakin tinggi dan lebih banyak dibandingkan pemakaian lemak. Protein atau asam amino membantu sebagai kunci enzimatik pada setiap tahapan metabolisme tetapi memberikan kontribusi minimal dalam sintesis protein. Namun, pada situasi latihan yg ekstrem, misalnya pada latihan aerobik durasi panjang, protein dapat dipecah membentuk energi (Ehrman et al., 2017).
Performa endurance telah dilaporkan dapat diperbaiki dengan menjaga kondisi euglikemia selama tahap akhir latihan yang panjang dan atau dengan menghemat penyimpanan glikogen otot yang diduga menunda terjadinya kelelahan dan mempertahankan intensitas latihan selama lebih dari 45 menit dengan suplementasi karbohidrat (Vandenbogaerde et al., 2000). Oleh karena itu, strategi nutrisi pascalatihan telah menjadi tujuan dari beberapa penelitian untuk pemulihan latihan yang optimal. Tulisan ini akan memberikan gambaran dan diskusi beberapa penelitian dengan fokus pada efek pemberian karbohidrat dan protein setelah latihan pada fase pemulihan.

\section{HASIL DAN PEMBAHASAN}

\section{Sumber Energi Selama Latihan Tipe} Endurance

\section{a. Adenosin Trifosfat (ATP)}

Fisiologi olahraga merupakan bidang studi yang berfokus pada respons tubuh terhadap olahraga dan jenis kegiatan fisik lainnya. Dalam mempelajari studi ini proses metabolik yang penting yaitu bagaimana sel otot mengubah bahan makanan dengan atau tanpa oksigen menjadi suatu energi kimiawi (dalam bentuk adenosin trifosfat, ATP) untuk melaksanakan aktivitas fisik. Pergerakan yang terjadi oleh sistem neuromuskular tidak bisa tanpa adanya 
produksi ATP. Hal ini merupakan kebutuhan dalam hidup organisme terutama manusia demi kelangsungan hidup. Hampir semua energi yang dihasilkan membutuhkan adanya oksigen, sehingga metabolisme sangat bergantung pada sistem kardiorespirasi (Plowman dan Smith, 2013).

Adenosina trifosfat adalah suatu molekul berenergi tinggi, yaitu ketika gugus fosfat dihilangkan, energi akan ditransfer. ATP terdiri dari basa nitrogen berkarbon (adenin), ribosa, dan 3 gugus fosfat yang terikat dengan ikatan kimia. Reaksi energi ATP bersifat bolak-balik. Sintesis dari ADP (adenin+ribosa) dan fosfat memerlukan energi. Penambahan gugus fosfat ini disebut fosforilasi, sedangkan hidrolisis proses sebaliknya yang melepaskan energi dengan berpasangan pada reaksi kimia lain (coupled reaction). Oleh karena itu, ATP merupakan sumber energi segera yang dibutuhkan semua sel (Ehrman et al., 2017; Widmaier et al., 2013).

Otot skeletal hanya mengandung ATP yang cukup untuk kontraksi maksimal selama 3 detik, dan ATP total dalam tubuh sekitar $0.1 \mathrm{~kg}$, yang hanya cukup untuk memenuhi kebutuhan fungsi fisiologis tubuh selama beberapa menit. Hal ini terjadi jika ATP tidak dibentuk kembali setelah digunakan. Oleh karena itu, tubuh dengan konstan mensintesis kembali ATP. Tiga proses dalam sintesis ATP yaitu interaksi antara ADP dengan kreatin fosfat, respirasi anaerob pada sitoplasma sel dan respirasi aerob di mitokondria sel. Otot yang istirahat mengandung kreatin fosfat lebih banyak daripada ATP untuk regenerasi ATP, namun pada otot yang bekerja, simpanan kreatin fosfat ini habis dalam 15-30 detik (Widmaier et al., 2013).

\section{b. Respirasi Seluler}

Respirasi seluler adalah proses transfer energi dalam sel dari makanan membentuk ATP yang bergantung pada ketersediaan oksigen oleh sistem respirasi. Respirasi seluler dapat terjadi dengan ketersediaan oksigen yang disebut respirasi aerob dan tanpa oksigen yang disebut respirasi anaerob.

Beberapa pokok dasar dapat menjelaskan proses respirasi seluler. Karbohidrat, lemak dan protein yang semuanya merupakan tiga nutrisi makanan utama sebagai penyedia bahan bakar atau substrat untuk produksi ATP melalui kerja enzim. Bentuk substrat yang penting dan segera dapat digunakan yaitu glukosa, asam lemak dan asam amino. Metabolisme karbohidrat, lemak dan protein akan membentuk substansi intermediet universal, yaitu asetil koenzim A (asetil KoA). Meskipun glikolisis menghasilkan ATP dalam jumlah sedikit seperti asetil KoA, 
kedua proses beta oksidasi dan deaminasi oksidatif atau transaminasi merupakan tahapan persiapan sederhana dari asam lemak dan asam amino dikonversi menjadi asetil KoA sebagai substrat universal untuk proses metabolisme selanjutnya. Proses akhir lanjutan yaitu jalur metabolisme primer dari siklus Krebs, sistem transport elektron (ETS) dan fosforilasi oksidatif (OP). Jalur ini umum sama untuk semua tipe prekursor makanan (Maughan, 2008).

Fosforilasi oksidatif merupakan jalur aerobik yang bergantung dengan adanya oksigen untuk produksi ATP dari pemecahan karbohidrat dan lemak. Semua reaksi terjadi di mitokondria yang berlokasi pada sitosol dekat dengan unit kontraktil. Kecepatan produksi energi jalur ini lebih lambat dibandingkan ATP-fosfokreatin dan sistem glikolisis, tetapi jumlah ATP lebih besar. Oleh karena itu lebih aktif selama latihan aerob intensitas ringan hingga moderat.

\section{Kelelahan}

Kelelahan merupakan sensasi yang dialami individu segera setelah inisiasi aktivitas intens, seperti yang diamati dengan pengurangan kemampuan menghasilkan kekuatan. Kelemahan yang berkelanjutan setelah aktivitas, bisa bertahan selama berhari-hari atau bahkan berminggu-minggu. Terdapat beragam mekanisme yang bertanggung jawab atas penurunan kinerja oleh aktivitas yang memberikan tekanan yang berat pada beberapa sistem organ, jaringan dan sel (Kitani, 2011).

Rantai komando dari kemauan/kesadaran dalam melakukan suatu gerakan sampai kekuatan yang dapat terukur merupakan rantai yang panjang. Selama latihan, perubahan terjadi pada semua langkah/tahapan/rantai yang menghasilkan gerakan yaitu dari korteks motorik hingga ke miofibril. Hampir semua kasus kelelahan otot terjadi pada neuromuscular junction yang disebut juga sebagai kelelahan perifer, sedangkan yang terjadi pada bagian proksimal neuromuscular junction disebut sebagai kelelahan sentral. Kelelahan sentral merupakan penurunan kekuatan yang disebabkan berkurangnya frekuensi letupan motorneuron yang terlibat, sedangkan kelelahan perifer terjadi penurunan kekuatan meskipun dengan pengaktifan serabut otot oleh motorneuron (Boyas, 2010)

Mekanisme muskular dan sentral diduga menentukan performa fisik selama kelelahan fisik. Mekanisme muskular yaitu berkurangnya glikogen dan fosfokreatin sebagai sumber energi. Mekanisme sentral merupakan bagian dari kelelahan sentral pada tingkat supraspinal berupa sinyal 
inhibisi ke korteks selama kelelahan (Taylor et al., 2000). Terdapat beragam mekanisme yang bertanggung jawab atas penurunan kinerja oleh aktivitas yang memberikan tekanan yang berat pada beberapa sistem organ, jaringan dan sel. Pada tingkat sel otot, penggunaan ATP meningkat secara dramatis dalam upaya untuk mengatasi kebutuhan energi dalam proses utama yang terlibat dalam eksitasi dan kontraksi, yaitu pertukaran $\mathrm{Na}^{+} / \mathrm{K}^{+}$ pada sarcolemma, sequestrasi kalsium retikulum sarcoplasmic dan siklus aktomiosin (Green, 1997)

Transfer fosfat berenergi tinggi, glikolisis dan fosforilasi oksidatif direkrut dalam upaya mempertahankan kadar ATP. Tingkat produksi ATP tidak dapat menyesuaikan tingkat pemakaian ATP pada aktivitas intens, dan pengurangan ATP terjadi disertai akumulasi berbagai produk sampingan metabolik seperti ion hidrogen, anorganik fosfat, AMP, ADP dan IMP. Produk samping selektif ini diyakini mengganggu keseimbangan $\mathrm{Na}^{+} / \mathrm{K}^{+}$, siklus $\mathrm{Ca}^{2+}$ dan interaksi aktomiosin, yang akhirnya mengakibatkan kelelahan. Penghentian aktivitas dan normalisasi potensial energi seluler menyebabkan pemulihan kekuatan yang cepat. Kelelahan jenis ini sering disebut sebagai metabolism (Green, 1997).
Penipisan substrat intraselular yaitu glikogen dapat terjadi akibat aktivitas intensitas tinggi yang berulang juga merupakan indikasi adanya kelelahan. Kelelahan mudah terlihat saat sumber daya seluler habis, karena glikogen adalah bahan bakar fundamental yang digunakan untuk menopang glikolisis dan fosforilasi oksidatif.

Intensitas dan durasi latihan dihubungkan dengan kecepatan degradasi glikogen otot, yang meningkat dengan intensitas dan menurun dengan durasi (Graham et al., 2001). Penggunaan glikogen bergantung pada ketersediaan substrat ini sebelum latihan sehingga ketersediaan glikogen sebelum latihan dapat memodulasi metabolisme glikogen selama latihan berikutnya (Hargreaves, 2004).

Penelitian sebelumnya menunjukkan adanya suatu hubungan yang erat antara konsentrasi glikogen otot dan kapasitas latihan yang menunjukkan kelelahan terjadi bersamaan dengan simpanan glikogen otot yang sangat rendah (Bergstrom and Hultman, 1967). Hal ini memberikan suatu gambaran akan peningkatan glikogen otot sebelum latihan akan menentukan kemampuan untuk melakukan latihan intensitas sedang-tinggi dengan durasi yang lama. 
Intervensi nutrisi berbasis bukti melalui pengaturan resintesis glikogen yang dihubungkan dengan kelelahan dan performa/kapasitas latihan dan pemulihan setelah latihan/olahraga, dapat dilakukan melalui manipulasi beberapa variabel nutrisi yang berbeda seperti komposisi nutrisi, kuantitas, waktu konsumsi nutrien, dll.

\section{Peranan Karbohidrat Selama Fase Pemulihan Pasca-Latihan}

Karbohidrat merupakan senyawa yang tersusun dari kombinasi karbon, hidrogen, dan atom oksigen dengan formula $\mathrm{C}_{\mathrm{n}} \mathrm{H}_{2 \mathrm{n}} \mathrm{O}_{\mathrm{n}}$ sebagai salah satu sumber utama bahan bakar pembentukan energi. Karbohidrat menyediakan kira-kira 4 kkal energi/g. Pada saat istirahat kira-kira setengah sumber energi berasal dari karbohidrat, dan sisanya dari lemak. Setelah makan, hampir semua karbohidrat masuk ke dalam aliran darah melalui traktus gastrointestinal sebagai molekul glukosa 6 karbon yang akan ditransport ke semua jaringan. Proses pemakaian glukosa ke dalam otot skeletal atau hepar memiliki dua tujuan akhir, yaitu masuk ke jalur metabolisme sintesis ATP (glikolisis) atau penyimpanan di sitoplasma sel sebagai glikogen. Glikogen otot skeletal akan dipecah dan digunakan untuk sintesis ATP selama latihan yang intens, sedangkan glikogen hepar dipecah menjadi glukosa dan dilepaskan ke sirkulasi untuk menjaga kadar glukosa darah. Kira-kira 2000 kkal (500 g) disimpan sebagai glikogen otot dan 500 kkal (125 g) sebagai glikogen hepar (Widmaier et al., 2013).

Beberapa fakta mengenai karbohidrat sebagai bahan bakar selama latihan berdasarkan American College of Sport Medicine (2009) dan American Dietetic Association (1987) bahwa semakin tinggi intensitas latihan (baik continous atau intermitten, aerobik, anaerobik, atau aerobik-anaerobik), semakin penting glikogen sebagai sumber energi; tubuh hanya dapat menyimpan karbohidrat dalam jumlah yang terbatas, tetapi latihan dapat meningkatkan kemampuan menyimpan karbohidrat dan menghemat karbohidrat. Meskipun demikian, setelah latihan endurance yang berat selama 60-90 menit, penyimpanan glikogen berkurang dan habis dalam 120 menit. Glikogen otot juga dapat berkurang dalam 15-30 menit latihan dengan intensitas maksimal-supramaksimal. Kelelahan dan keletihan berhubungan dengan kekurangan glikogen selama aktivitas durasi panjang dengan intensitas tinggi, sehingga asupan yang adekuat terhadap glikogen otot dibutuhkan untuk mencegah kelelahan dan diisi ulang sebelum aktivitas yang lebih berat dilakukan lagi (Plowman dan Smith, 2013). 
Konsumsi makanan/minuman setelah latihan dibandingkan tanpa konsumsi makanan/minuman terhadap perbaikan pada fase pemulihan pasca-latihan terbukti efektif.8Beberapa studi telah meneliti metode dalam meningkatkan kecepatan sintesis glikogen kembali setelah latihan, karena sintesis glikogen komplit terjadi dalam 24 jam. Suplementasi karbohidrat 1$1,5 \mathrm{~g} / \mathrm{kg}$ sebaiknya dikonsumsi segera setelah latihan dan dilanjutkan setiap 2 jam selama 6 jam setelah latihan akan memaksimalkan resintesis glikogen otot. Sintesis glikogen sebaliknya akan menurun jika asupan karbohidrat ditunda selama 2 jam (Ivy et al,1988).

Diet karbohidrat terdapat dalam berbagai bentuk, terdiri dari monosakarida seperti glukosa, fruktosa dan galaktosa; disakarida seperti maltosa, sukrosa dan laktosa; dan polisakarida seperti maltodekstrin dan pati. Tingkat pencernaan, penyerapan usus dan metabolisme hati karbohidrat merupakan penentu utama pengiriman karbohidrat ke jaringan otot rangka.Oleh karena itu, faktor-faktor ini penting dipertimbangkan saat memilih strategi nutrisi untuk mengoptimalkannya pengiriman karbohidrat selama dan setelah berolahraga/latihan.

Sebelum diserap ke seluruh usus dan memasuki sirkulasi sistemik, karbohidrat harus dihidrolisis terlebih dahulu menjadi penyusun monomernya (glukosa, fruktosa dan /galaktosa). Proses ini telah terjadi dimulai dari kerja enzim amilase di rongga mulut dan sebagian besar oleh enzim amilase di usus halus serta enzim yang berlokasi pada membran luminal sel epitel usus halus (brush border). Monosakarida ini kemudian akan ditransport melewati epitel intestinal ke dalam darah. Fruktosa masuk ke dalam sel epitel melalui difusi terfasilitasi via transporter glukosa (GLUT), sedangkan glukosa dan galaktosa masuk melalui transport aktif sekunder berpasangan $\mathrm{Na}^{+}$via sodium-glucose transporter (SGLT). Setelah meninggalkan sel epitel dan masuk ke cairan interstisial melalui protein GLUT pada membran basolateral sel epitel, monosakarida berdifusi ke dalam darah melalui por-pori kapiler (Widmaier et al., 2013).

Proses pencernaan dan penyerapan ini menjadi faktor yang mempengaruhi sintesis glikogen otot setelah konsumsi karbohidrat setelah latihan. Sintesis glikogen otot menjadi lebih efektif pada suplementasi karbohidrat dengan interval pemberian yang lebih singkat (15-60 menit) dibandingkan dengan bolus karbohidrat dengan jumlah besar dan studi terbaru menyebutkan bahwa peningkatan sintesis glikogen otot tidak optimal jika diberikan dengan interval 2 jam, karena resintesis yang cepat terjadi dalam 2 jam pertama 
setelah latihan (Jentjens et al, 2003; Ivy et al, 2002; Zawadzki et al, 1992).

Pola bifasik tampak pada resintesis glikogen setelah latihan (Maehlum et al., 1977). Pada fase awal, terdapat peningkatan resintesis glikogen yang cepat yang tidak bergantung pada konsentrasi insulin dan berlangsung selama 30-60 menit setelah latihan (Jentjens and Jeukendrup, 2003). Kecepatan resintesis ini akan cepat menurun jika tidak disertai dengan asupan karbohidrat oleh karena hal ini sejalan dengan peningkatan uptake glukosa setelah latihan oleh peningkatan translokasi GLUT4 dua kali lipat segera setelah latihan sebelum akhirnya menurun secara bertahap (Goodyear et al., 1990). Hal ini juga diduga terjadi saat kadar glikogen yang sangat rendah pada akhir latihan (Jentjens and Jeukendrup, 2003; Maehlum et al., 1977). Pada fase kedua resintesis glikogen terjadi pada kecepatan yang lebih rendah $(80 \%$ lebih rendah) dan ditandai oleh afinitas uptake glukosa otot dan stimulasi insulin (Danforth, 1965). Insulin diduga meningkat dengan asupan karbohidrat pada fase ini yang meningkatkan kecepatan sintesis glikogen meskipun lebih rendah dibandingkan pada fase awal (Ivy et al., 1988).

Tipe karbohidrat yang dikonsumsi juga mempengaruhi kecepatan sintesis glikogen otot pasca-latihan seperti juga kapan waktu interval pemberian. Perbedaan ini kemungkinan disebabkan oleh perbedaan proses pencernaan karbohidrat dan kinetika selama latihan dan pemulihan pasca-latihan. Uptake glukosa oleh sel otot yang dimediasi oleh insulin menjadi faktor penting yang menentukan kecepatan resintesis glikogen otot (Jentjens and Jeukendrup, 2003). Peningkatan respon insulin terhadap karbohidrat dengan indeks glikemik yang tinggi berdampak pada percepatan sintesis glikogen otot dibandingkan dengan indeks glikemik yang rendah, terutama pada fase akut $(<6$ jam fase pemulihan) (Walton dan Rhodes, 1997). Glukosa adalah penyusun sebagian besar disakarida dan polisakarida dan juga merupakan bahan bakar seluler utama sumber di hampir semua jaringan manusia. Respon insulin terhadap glukosa umumnya lebih besar dibandingkan fruktosa. Hal ini disebabkan metabolisme fruktosa sebagian besar terjadi di hepar, sedangkan mayoritas glukosa akan melewati hepar dan masuk ke sirkulasi sitemik untuk disimpan dan atau dioksidasi oleh otot. Respon insulin ini berimplikasi pada penyimpanan glikogen pada fase pemulihan pasca-latihan. Ketika fruktosa diinfuskan ke dalam darah akan menghasilkan empat kali lebih besar pada simpanan glikogen hepar dibandingkan glukosa, namun kecepatan simpanan glikogen pada otot skeletal lebih besar 
setelah pemberian glukosa dibandingkan fruktosa (Gonzales et al., 2017).

Kapasitas untuk melakukan latihan intensitas menengah hingga tinggi ditentukan selain oleh pemulihan cepat simpanan glikogen otot tetapi juga simpanan glikogen hati. Oleh karenanya beberapa studi menunjukkan bahwa konsumsi glukosa bersama fruktosa meningkatkan kecepatan pengisian glikogen hepar dua kali lebih cepat dibandingkan konsumsi glukosa saja. Hal ini dikarenakan tingkat ketersediaan glukosa yang telah dikonsumsi dalam sirkulasi tampaknya dibatasi oleh kapasitas transporter intestinal. Karena penyerapan fruktosa usus menggunakan transporter yang berbeda, maka mekanisme menggabungkan konsumsi fruktosa dan glukosa mengambil keuntungan dari kedua mekanisme transportasi tersebut, sehingga meningkatkan kapasitas total untuk menyerap karbohidrat. Namun hasil yang berbeda didapatkan pada glikogen otot setelah latihan tidak mempercepat pengisian kembali simpanan glikogen pada pemberian kombinasi glikosa-fruktosa. Meskipun demikian, mayoritas penelitian menunjukkan insulinemia yang lebih rendah selama pemulihan pasca-latihan dengan konsumsi glukosa-fruktosa dibandingkan glukosa saja. Adanya insulinemia yang lebih rendah maka kemungkinan penyimpanan glikogen tampaknya sama seperti glikogen hepar, selain itu ditunjukkan pula dengan performa dapat diperbaiki 1-9\% lebih besar dapat terjadi dengan konsumsi kombinasi glukosa-fruktosa jika sejumlah besar karbohidrat dicerna (> 1,4 g/menit) (Gonzales et al., 2017).

\section{Peranan Protein Selama Fase Pemulihan} Pasca-Latihan

Kualitas dan kuantitas massa otot skeletal bergantung pada asupan protein yang dikonsumsi. Performa atau kinerja latihan meningkatkan remodelling protein otot dengan merangsang tingkat sintesis protein selama beberapa jam setelah latihan, yang dapat dioptimalkan dengan mengkonsumsi protein selama periode pemulihan pasca-latihan.

Total penggunaan energi selama latihan endurance sebesar 5-15\% disediakan oleh protein, yang jumlah ini kurang jika dibandingkan kontribusi karbohidrat. Peningkatan kebutuhan akan produksi ATP dapat meningkatkan penggunaan asam amino sebagai bahan bakar otot. Kerusakan struktural sel otot dapat terjadi pada latihan yang berat dan membutuhkan sintesis protein untuk perbaikannya. Kelompok asam amino yang dapat digunakan langsung sebagai bahan bakar adalah kelompok branch chain amino 
acids (BCAA) seperti leusin, isoleusin dan valin. Hal ini tampak dengan menurunnya konsentrasi BCAA dalam darah dan meningkatnya kadar enzim yang memetabolisme BCAA selama latihan endurance. Studi menunjukkan konsumsi karbohidrat menurunkan pemecahan protein. Meningkatnya ketersediaan glikogen otot atau hormon yang responsif terhadap karbohidrat seperti insulin memediasi efek ini. Selama latihan pada kondisi rendah karbohidrat, BCAA lebih banyak dipecah untuk menyediakan kerangka karbon yang digunakan hepar untuk proses glukoneogenesis. Meskipun demikian, protein hanya menyediakan tidak lebih dari $15 \%$ pada total energi bahkan pada saat simpanan karbohidrat rendah (Rankin, 1999).

Peningkatan resintesis glikogen selama 6 jam fase pemulihan pasca-latihan dan peningkatan respon insulin tampak pada pemberian kombinasi karbohidrat dan protein (Berardi et al, 2006). Betts et al. menyebutkan bahwa beberapa faktor diduga berhubungan dengan kelelahan akan mempengaruhi performa seperti kandungan protein, frekuensi pemberian/suplementasi dan lainnya seperti asidosis.

Penambahan protein pada minuman berkarbohidrat pasca-latihan meningkatkan sintesis glikogen diduga melalui kerja sinergis dalam meningkatkan kadar insulin sehingga meningkatkan deposit glukosa otot (van Loon et al., 2000). Namun hasil ini tidak ditemukan perbedaan pada penelitian oleh Carrithers et al. (2000) setelah pemberian pasca latihan minuman eukalori antara minuman berkarbohidrat, kombinasi karbohidrat dan protein serta minuman karbohidrat dengan asam amino setiap 30 menit selama 4 jam pada fase pemulihan setelah deplesi glikogen dengan sepeda ergometer. Berbeda dengan Ivy et al. (2002), terjadi peningkatan resintesis glikogen otot pada awal pasca latihan setelah bersepeda pada 70\%VO2max selama 2,5 jam yang mengkonsumsi minuman mengandung karbohidrat dan protein dibandingkan dengan mengkonsumsi minuman tinggi karbohidrat saja dan minuman karbohidrat rendah saja. Konsentrasi insulin pada tiga kelompok ini tidak ada perbedaan namun konsentrasi glukosa plasma lebih rendah pada kelompok minuman kombinasi karbohidrat dan protein. Hal ini diduga akibat peningkatan uptake glukosa dan relokasi pembuangan glukosa intrasellular 15 serta konsumsi karbohidrat di bawah ambang (< $1 \mathrm{~g} / \mathrm{kg}$ ) pasca latihan yang menguntungkan pada penyimpanan maksimal glikogen otot (Bishop, 2008).

Peningkatan anabolisme protein dan menurunnya kerusakan otot tampak dengan penambahan

protein pada 
makanan/minuman selama fase pemulihan pasca-latihan (Saunders et al., 2007). Peningkatan marker enzimatik kerusakan otot selama latihan endurance intensitas tinggi dan lama seperti kreatin kinase, mioglobin, kortisol dan laktat dehidrogenase dihubungkan dengan menurunnya performa (White et al., 2008).

Berdasarkan beberapa penelitian sebelumnya yang telah dipaparkan menunjukkan minuman mengandung protein yang dikonsumsi selama pemulihan pasca-latihan efektif memperbaiki proses pemulihan. Hal ini dapat disebabkan kandungan kalori yang lebih tinggi pada karbohidrat dan protein, dengan kalori tambahan protein sebagai substrat tambahan untuk resintesis glikogen melalui glukoneogenesis sehingga meningkatkan perbaikan pada fase pemulihan (Ivy et al., 1988). Penelitian terbaru menunjukkan bahwa 20 - 25 g protein kualitas tinggi dengan pemberian tunggal optimal untuk perbaikan fase pemulihan. Penelitian terhadap tipe protein, waktu pemberian dan efek distribusi protein selama pemulihan perlu dilakukan di masa mendatang (Bishop et al., 2008).

\section{KESIMPULAN}

Hubungan antara glikogen otot selama latihan intensitas sedang-tinggi dan onset kelelahan merupakan bagian sentral dari fase pemulihan sehingga penelitian sebelumnya berfokus pada efek intervensi nutrisi untuk memaksimalkan ketersediaan substrat ini. Meskipun demikian, jumlah/atau komposisi nutrisi yang tepat masih menjadi perdebatan dan pedoman atu petunjuk nutrisi untuk memperbaiki kapasitas latihan melalui peningkatan tingkat glikogen otot belum diikuti dengan penelitian mengenai metabolisme glikogen otot selama latihan intensitas sedang-tinggi yang berulang.

Kombinasi konsumsi makanan/ minuman mengandung karbohidrat dan protein mengambil banyak perhatian dari peneliti, namun beberapa faktor perancu seperti kandungan kalori dan adanya nutrien lain menyulitkan dalam melihat peranan yang tepat dari protein terhadap resintesis glikogen. Mekanisme fisiologis bagaimana penambahan protein pada karbohidrat dalam memperbaiki kapasitas latihan yang berkelanjutan masih dieperdebatkan dan harus diteliti lebih lanjut. Variabel lain seperti asupan makanan sehari-hari, pola tidur perlu dilakukan kontrol sehingga tidak mempengaruhi hasil penelitian. Jenis kelamin juga perlu diperhatikan untuk menyusun pedoman nutrisi bagi laki-laki dan perempuan yang mungkin tidak bisa diberlakukan kepada keduanya karena jenis kelamin mempengaruhi perbedaan dalam 
penggunaan simpanan karbohidrat endogen

yang lebih sedikit pada wanita dibandingkan laki-laki (Tarnopolsky et al., 1990).

\section{DAFTAR PUSTAKA}

American College of Sports Medicine, American Dietetic Association, and Dietitians of Canada, 2009. Nutrition and Athletic Performance. Joint Position Statement of the American Dietetic Association, Dietitians of Canada, and the Medicine and American College of Sports Medicine. Med. Sci. Sports Exerc.109:509-527.

Berardi, J.M., Price, T.B., Noreen, E.E., Lemon, P.W.R., 2006. Postexercise muscle glycogen recovery enhanced with a carbohydrate-protein supplement. Med. Sci. Sports Exerc. 38:1106-1113.

Bergstrom, J., Hermansen, L., Hultman, E., Saltin, B., 1967. Diet, muscle glycogen and physical performance. Acta Physiologica Scandinavica 71, 140-150.

Betts J.A., Williams, C., 2010. Short-Term Recovery from Prolonged Exercise Exploring the Potential for Protein Ingestion to Accentuate the Benefits of Carbohydrate Supplements. Sports Med 40: 941-959.

Bishop, P.A., Jones, E., Woods, K., 2008. Recovery from Training: A Brief Review. J. Strength Cond. Res. 229(3):1-10.

Boyas, S., Guevel, A., 2010. Neuromuscular fatigue in healthy muscle: underlying factors and adaptation mechanisms. Ann.Phys.Rehabil.Med. 54:88-108.
Carrithers, J.A., Williamson, D.L., Gallagher, P.M., Godard, M.P., Schulze, K.E., Trappe, S.W., 2000. Effects of postexercise carbohydrateprotein feedings on muscle glycogen restoration. J.Appl. Physiol. 88:1976-1982.

Danforth, W.H., 1965. Glycogen Synthetase activity in skeletal muscle. Interconversion of two forms and control of glycogen synthesis. J.Biol.Chem. 240: 588-593.

Ehrman, J.K., Kerrigan, D.J., Keteyian, S.J., 2017. Advanced Exercise Physiology: Essential Concepts and Applications. Human Kinetics: Champaign

Goodyear, L.J., Hirshman, M.F., King, P.A., Horton, E.D., Thompson, C.M., Horton E.S., 1990. Skeletal muscle plasma membrane glucose transport and glucose transporters after exercise. J.Appl. Physiol. 68:193198.

Graham, T.E., Adamo, K.B., Shearer, J., Marchand, I., Saltin, B., 2001. Proand macroglycogenolysis: relationship with exercise intensity and duration. J. Appl.Physiol. 90: 873-879.

Gonzales, J.T., Fuchs, C.J., Betts, J.A., van Loon, L.J., 2017. Glucose plus fructosa ingestion for Post- Exercise recovery-greater than the sum of its part?. Nutrients 9(4):E344.

Green, H.J., 1997. Mechanisms of muscle fatigue in intense exercise. J.Sport Science 15(3): 247-256.

Hargreaves, M., 2004. Muscle glycogen and metabolic regulation. The Proceedings of the Nutrition Society $63: 217-220$

Ivy, J.L., Katz, A.L., Cutler, C.L., 1988. Muscle glycogen synthesis after exercise:effect of time of 
carbohydrate ingestion. J. Appl. Physiol. 64(4):1480-1485.

Ivy, J.L., Goforth, H.W., Damon, B.M., McCauley, T.R., Parsons, E.C., Price, T.B., 2002. Early postexercise muscle glycogen recovery is enhanced with a carbohydrateprotein supplement. J. Appl. Physiol.93:1337-1344.

Jentjens, R.L., Venables, M.C., Jeukendrup, A.E., 2004. Oxidation of exogenous glucose, sucrose, and maltoseduring prolonged cycling exercise. J. Appl. Physiol. 96:1285-1291.

Jentjens, R.L., Jeukendrup, A.E., 2003. Determinants of post-exercise glycogen synthesis during short term recovery. Int. J. Sport Nutr. Exerc. Metab.33(2):117-144.

Maehlum, S., Hostmark, A.T., Hermansen, L., 1977. Synthesis of muscle glycogen during recovery after prolonged severe exercise in diabetic and non-diabetic subjects. Scan. J.Clin.Lab.Invest. 37:309-316.

Kitani, T., 2011. Term Comitte of Japanese Society of Fatigue Science. Nihon Hirougakkasishi (in japanese) 6:1.

Maughan, R.J., 2008. Nutrition in Sport. John Wiley \& Sons

Plowman, S.A., Smith, D.L., 2013. Exercise Physiology for Health Fitness and Performance Lippincott Williams \& Wilkins: Philadelphia

Rankin, J.W., 1999. Role of protein in exercise. Clin. Sports Med. 18(3):499-511.

Saunders, M.J., Luden, N.D., Herrcick, J.E., 2007. Consumption of an oral carbohydrate- protein gel improves cycling endurance and prevents postexercise muscle damage. J. Strength Cond. Res, 21(3):678-684.
Taylor, J.L., Allen, G.M., Butter, J.E., Gandevia, S.C., 2000. Supraspinal fatigue during intermittent maximal voluntary contractions of the human elbow flexors. J.Appl.Pjysiol. 89:303-313

Tarnopolsky, L.J., MacDougall, J.D., Atkinson S. A., Tarnopolsky M. A. \& Sutton J. R. (1990) Gender differences in substrate for endurance exercise. J. Appl. Physiol. 68:302-308.

Van Loon, L.J., Saris, W.M., Ruijshoopanda, M.K., Wagenmakers, A.M., 2000. Maximizing

postexercise muscle glycogen synthesis: Carbohydrate supplementation and the application of amino acid or protein hydrolysate. Am. J. Clin. Nutr. 72:106-111.

Vandenbogaerde, T.J., Hopkins, W.G., 2011. Effects of acute carbohydrate supplementation on endurance performance: A meta-analysis. Sports Med. 41:773-792.

Viru, A., 1999. Postexercise recovery period: carbohydrate protein metabolism. Scand. J. Med. Sri. Sports 6: 2-14.

Walton, P., Rhodes, E.C., 1997. Glycaemic index and optimal performance. Sports Med. 23(3):164-72.

White, J.P., Wilson, J.M., Austin, K.G., Greer, B.K., St. John, N., Panton, L.B., 2008. Effect of a carbohydrateprotein supplement timing on acute exercise-induced muscle damage. J.Int. Soc. Sports Nutr. 5:5.

Widmaier, E., Raff, H., Strang, K., 2013. Human Physiology: The Mechanisms of Body Function. McGraw-Hill, Boston.

Zawadzki, K.M., Yaspelkis, B.B., Ivy, J.L., 1992. Carbohydrate-protein complex increases the rate of muscle glycogen 
storage after exercise. J. Appl.

Physiol. 72:1854-1859. 